\title{
PENGEMBANGAN PERANGKAT PEMBELAJARAN AKUNTANSI BERBASIS INKUIRI DI SMA NEGERI 2 BLITAR
}

\author{
Primasa Minerva Nagari \\ Universitas Negeri Malang
}

E-mail: primasaminerva@gmail.com

\begin{abstract}
This research describe about the development of learning instruments of accounting using Inquiry-Base at State Senior High School 2 Blitar. The use of various instruments will increase learning motivation and increase students' learning results. The aims of this development is to yield a learning instrument of accounting using inquiry-base which has been validated so that it is proper to be used in accounting learning process. This study is research and development using Borg and Gall development model. This study used some steps, such as 1) the initial situation analysis, 2) development of the product, 3) create product, 4) test of validity , 5) revision of product I, 6) feasibility ,7) revision of product I, and 8) final product. Validation was done by three experts; material expert, education expert, and users (students). According to the result of this study, it is suggested especially for teacher to utilize learning instruments using inquiry-base in learning process. In addition, the instruments could be developed in other material as well for better learning process.
\end{abstract}

Keyword: accounting, learning istruments, inquiry

Abstrak: Penelitian ini bertujuan menghasilkan produk berupa perangkat pembelajaran akuntansi berbasis inkuiri yang telah melalui proses validasi sehingga dinyatakan layak digunakan dalam proses pembelajaran akuntansi.Jenis penelitian ini merupakan penelitian pengembangan dengan model pengembangan Borg and Gall. Tahapan yang digunakan meliputi1) analisis situasi awal, 2) pengembangan rancangan produk, 3) membuat produk, 4) uji validitas, 5) revisi produk I, 6) uji kelayakan, 7) revisi produk 2, dan 8) produk akhir. Validasi perangkat pembelajaran dilakukan oleh tiga subyek yaitu ahli materi, ahli pendidikan dan pengguna (siswa). Berdasarkan hasil penelitian ini disarankan kepada guru khususnya,untuk memanfaatkan perangkat pembelajaran berbasis inkuri dalam proses pembelajaran dengan maksimal. Selain itu, untuk proses pembelajaran yang lebih baik lagi juga dapat dikembangkan perangkat pembelajaran akuntansi berbasis inkuiri pada materi lain. 
Pendidikan yang berkualitas dapat menentukan kualitas bangsa agar tidak tertinggal dengan bangsa lain. Untuk itu, pembaharuan pendidikan sangat dibutuhkan dan menjadi tuntunan dalam meningkatkan kualitas pendidikan nasional.

Untuk meningkatkan kualitas pendidikan nasional, maka pendidik harus bisa meningkatkan kualitas pengajarannya dalam proses belajar mengajar. Seperti yang dituliskan Depdiknas dalam (Setiawan, 2013: 2), agar proses tersebut terlaksana, diperlukan peran guru sebagai pengarah kegiatan belajar mengajar sehingga siswa tidak hanya memperoleh pengetahuan namun juga mampu membangun pengetahuan untuk dirinya sendiri, sehingga pembelajaran berpusat pada siswa bukan berpusat pada guru. Berkaitan dengan hal tersebut, sistem penyelenggaraan pendidikan termasuk pembelajaran dan penilaian hasil belajar siswa, diharapkan dapat berubah dari pola yang sebelumnya lebih berpusat pada kegiatan mengajar guru (teacher centered) dan berorientasi pada materi pejalaran (subject matter oriented) ke pola yang lebih berpusat pad akegiatan siswa (student centered) dan berorientasi pada pengembangan kecakapan hidup siswa (life skills) yang terdiri atas kecakapan berpikir, kecakapan sosial, kecakapan akademik, dan kecakapan vokasional (Depdiknas, 2003a).

Untuk mencapai tujuan pembelajaran akuntansi di sekolah menengah atas, diperlukan kemampuan guru dalam penyusun perangkat pembelajaran yang baik agar tujuan pembelajaran tercapai. Berdasarkan pernyataan di atas, perangkat pembelajaran berbasis inkuiri sangatlah tepat untuk dikembangkan agar tujuan pembelajaran akuntansi tercapai. Dalam penelitian dan pengembangan ini akan dibatasi dengan perangkat berupa modul an rancangan pelaksanaan pembelajaran. Senada dengan Suparno dalam (Iriati, 2012:3) yang mengemukakan bahwa sebelum guru mengajar (tahap persiapan) seorang guru diharapkan mempersiapkan bahan yang mau diajarkan, mempersiapkan alat-alat peraga/praktikum yang akan digunakan, mempersiapkan pertanyaan dan arahan untuk memancing siswa aktif belajar, mempelajari keadaan siswa, mengerti kelemahan dan kelebihan siswa, serta mempelajari pengetahuan awal siswa, kesemuanya ini akan terurai pelaksanaannya di dalam perangkat pembelajaran.

Perangkat pembelajaran adalah sekumpulan media atau sarana yang digunakan oleh guru dan siswa dalam proses pembelajaran di kelas, serangkaian perangkat pembelajaran harus dipersiapkan seorang guru dalam menghadapi pembelajaran di kelas (Suhardi, 2007:24). Faktor - faktor keberhasilan pembelajaran akuntansi meliputi guru, murid, buku buku penunjang, rencana pelaksanaan pembelajaran (RPP), silabus, standar kompetensi dan kompentensi dasar. Dalam menyusun suatu perangkat pembelajaran, guru diharapkan menyesuaikan tujuan apa yang ingin dicapai setelah proses belajar mengajar. Menurut Peraturan Pemerintah (PP) Nomor 19 Tahun 2005 tentang Standar Nasional Pendidikan Pasal 20, "perencanaan proses pembelajaran meliputi silabus dan rencana pelaksanaan pembelajaran yang memuat sekurang-kurangnya tujuan pembelajaran, materi ajar, metode pengajaran, sumber belajar, dan penilaian hasil belajar".

Penelitian dan pengembangan ini diharapkan dapat menghasilkan produk akhir sebuah perangkat pembelajaran akuntansi berbasis inkuri yang dapat digunakan dalam proses pembelajaran akuntansi di sekolah menengah atas. Perangkat pembelajaran akuntansi dalam penelitian dan pengembangan ini terdiri dari rencana pelaksanaan pembelajaran dan modul.

Untuk rencana pelaksanaan pembelajaran (RPP) juga akan disusun sesuai dengan kurikulum yang sedang dipakai, yaitu Kurikulum 2013. Rencana pelaksaan pembelajaran disusun berdasarkan silabus yang ada, jadi materi dan tujuan akademik maupun non akademik yang akan tercermin dalam rancangan pelaksaan pembelajaran akuntansi ini.

Modul akuntansi adalah bahan ajar akuntansi yang akan dijadikan salah satu sumber belajar siswa dalam belajar akuntansi di sekolah menengah atas. Modul yang akan disusun akan dibuat semenarik mungkin dengan bahasa yang mudah dipahami dan warna yang sesuai, 
sehingga siswa juga akan tertarik untuk belajar. Modul akan disusun sesuai dengan kurikulum yang dipakai, yaitu Kurikulum 2013. Modul yang dibuat mencangkup materi siklus akuntansi perusahaan jasa yang diajarkan di sekolah menengah atas kelas XII semester genap, yang dibuat berdasarkan silabus yang ada dan rancangan pelaksanaan pembelajaran yang telah disusun. Jadi semua perangkat pembelajaran meningkatkan hasil belajar akuntansi siswa pula.

Penelitian dan pengembangan perangkat pembelajaran akuntansi berbasis inkuiri ini diharapkan dapat menunjang prestasi belaja siswa dalam pembelajaran akuntansi, sehingga siswa dapat megerjakan soal latihan dengan benar, dapat mencari teori secara mandiri, sehingga hasil belajarnya meningkat pula. Perangkat pembelajaran akuntansi berbasis inkuiri ini dapat menjadi referensi perangkat pembelajaran bagi guru akuntansi sebagai patokan dalam melaksanakan proses pembelajaran dan strategi pembelajaran akuntansi dalam kelas dalam kelas. Seperti yang diungkapkan Heinich dalam (Santyasa, 2006:26) "bahwa pembelajaran tidak tergantung pada guru, instruktor-independent, intruction, atau juga sebagai "self-intruction". Jadi dengan basis inkuri ini siswa dituntut untuk menemukan sendiri teori yang ada dengan pikiran kritis.

\section{METODE}

Model penelitian pengembangan yang digunakan dalam penelitian ini adalah model pengembangan Borg and Gall (1983). Hal ini dikarenakan model dari Borg and Gall lebih sederhana dalam pengembangannya, dan tidak mengurangi kualitas dari produk yang dihasilkan. Menurut Borg and Gall dalam Sukmadinata (2010: 169 - 170) menjelaskan sepuluh langkah penelitian dan pengembangan yang akan dijadikan pedoman dalam pengembanganini, sebagai berikut

1. Research and information collecting (penelitian dan pengumpulan data yang meliputi pengukuran kebutuhan, kajian pustaka, pengamatan kelas).

2. Planning (Perencanaan)

Termasuk dalam langkah ini merumuskan kecakapan dan keahlian yang berkaitan dengan permasalahan.

3. Develop preliminary form of product (pengembangan draf produk awal) Termasuk dalam langkah ini adalah pengembangan bahan pembelajaran, proses pembelajaran dan instrument evaluasi.

4. Preliminary field testing (Melakukan uji coba awal)

5. Main product revision (Melakukan revisi atau menyempurnakan hasil uji coba)

6. Main field testing (Melakukan uji lapangan utama)

7. Operational product revision (Melakukan revisi terhadap produk hasil uji coba lapangan)

8. Operational field testing (Melakukan uji coba lapangan operasional)

9. Final product revision (Penyempurnaan produk akhir)

10. Dissemination and implementation ( menyebarluaskan produk/model yang dikembangkan.

Alasan pemilihan model ini juga karena mudah untuk diikuti langkah - langkahnya dan sesuai digunakan dalam penelitian pengembangan perangkat pembelajaran akuntansi berbasis inkuri untuk menunjang kemampuan berpikir kritris siswa di SMA Negeri 2 Blitar. Perangkat pembelajaran hasil pengembangan diujicobakan secara terbatas hanya kepada siswa kelas XII Ilmu sosial di SMA Negeri 2 Blitar dan guru akuntansi untuk digunakan dalam pembelajaran.

Berdasarkan pada prosedur pengembangan media di atas, maka dalam menyusun pengembangan media pembelajaran ini menggunakan model pengembangan dari Borg and Gall (1983) yang telah disesuaikan dengan kebutuhan, maka dalam penelitian ini mengambil delapan tahapan yaitu meliputi1) analisis situasi awal, 2) pengembangan rancangan produk, 
3) membuat produk, 4) uji validitas, 5) revisi produk I, 6) uji kelayakan, 7) revisi produk 2, dan 8) produk akhir. Validasi perangkat pembelajaran dilakukan oleh tiga subyek yaitu ahli materi, ahli pendidikan dan pengguna (siswa).

\section{HASIL PENGEMBANGAN}

Pengembangan perangkat pembelajaran akuntansi ini mengadaptasi model pengembangan dari Borg and Gall yang telah disesuaikan dengan karakter peserta didik dan lingkungan.

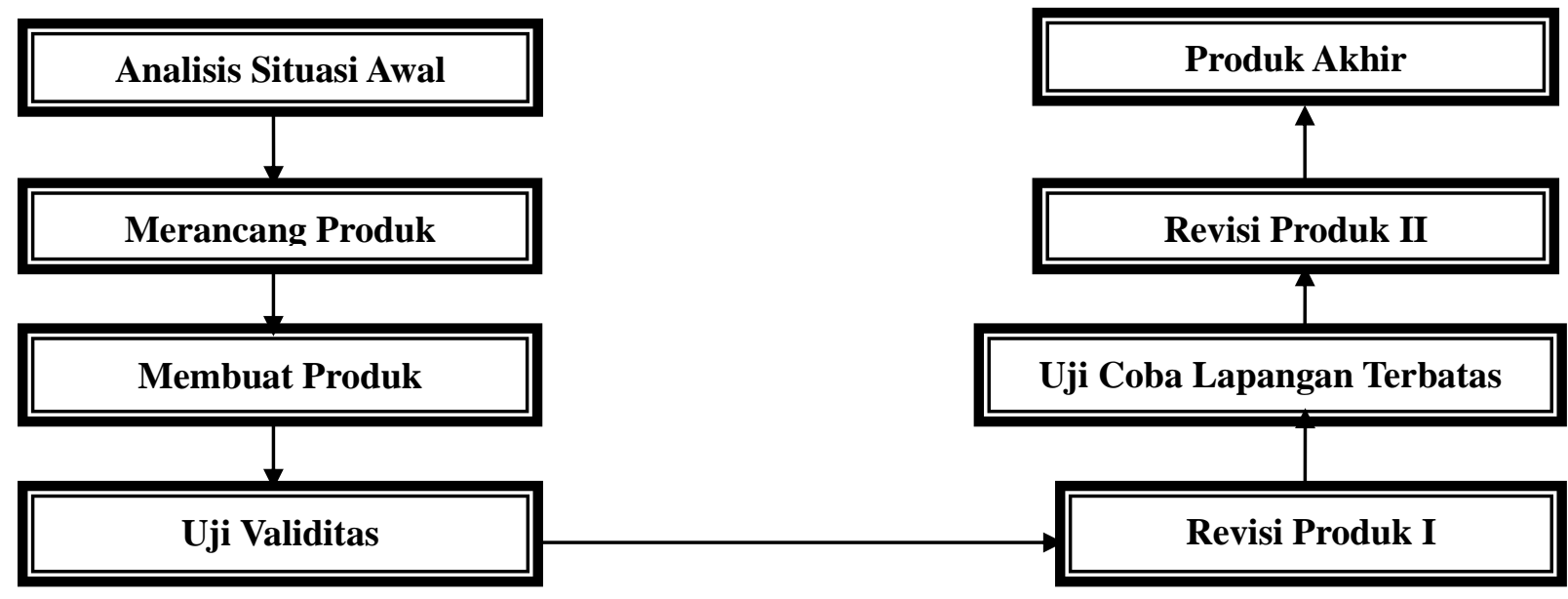

Gambar :Rancangan pengembangan Perangkat

Pembelajaran Akuntansi Berbasis Inkuiri (adaptasi : Borg and Gall)

\section{Penyajian Data Hasil Uji Coba}

\section{1) Deskripsi Pengembangan Perangkat Pembelajaran Akuntansi Berbasis Inkuri}

Pengembangan perangkat pembelajara akuntansi berbasis inkuiri dikembangkan sesuai dengan materi dan kurikulum yang dikembangkan saat ini. Prosedur pengembangan perangkat pembelajaran ini menggunakan prosedur Borg and Gall yang telah dimodifikasi untuk disesuaikan dengan keadaan lapangan, keterbatasan waktu, tenaga, dan biaya. Maka dalam penelitian ini, peneliti mengambil tujuh langkah dalam mengembangkan perangkat pembelajaran akuntansi berbasis inkuri, dengan langkah - langkah yaitu: (a) analisis situasi awal, (b) pengembangan rancangan perangkat pembelajaran akuntansi berbasis inkuri, (c) membuat produk, (d) penilaian uji validitas, (e) revisi perangkat pembelajaran akuntansi berbasis inkuri, (f) Uji coba lapangan terbatas (g) revisi perangkat pembelajaran akuntansi berbasis inkuiri II, (h) produk akhir.

\section{a. Analisis Situasi Awal}

Tahap analisis awal digunakan untuk mengetahui kebutuhan apa saja yang diperlukan guna mengatasi masalah yang ditemukan dalam kegiatan pembelajaran. Analisis situasi awal dilakukan dengan cara observasi dan wawancara dengan guru akuntansi di SMA Negeri 2 Blitar pada awal bulan Januari.

Berdasarkan hasil observasi dan wawancara dengan guru akuntansi di SMA Negeri 2 Blitar, dapat disimpulkan bahwa materi laporan keuangan perusahaan jasa merupakan materi yang akan sulit diterima oleh siswa. Maka dari itu diperlukan sebuah penunjang sebagai alat untuk membantu para siswa agar lebih mudah memahami materi laporan keuangan perusahaan jasa. Sebelumnya, guru akuntansi di SMA Negeri 2 Blitar telah belum pernah menggunakan modul pembelajaran yang berbasis inkuri, guru hanya menggunakan form saja 
Hasil wawancara dan analisis tersebut peneliti mencoba mengembangkan perangkat pembelajaran akuntansi berbasis inkuri untuk meningkatkan hasil belajar siswa.

Observasi dan wawancara tersebut menghasilkan tujuan penelitian pengembangan perangkat pembelajaran akuntansi berbasis inkuiri di SMA Negeri 2 Blitar ini, diharapkan dapat membantu siswa yang kurang memahami materi yang disampaikan oleh guru dan dapat meningkatkan motivasi siswa untuk berpikir kritis dalam mempelajari materi laporan keuangan perusahaan jasa. Perangkat pembelajaran akuntansi berbasis inkuri ini dapat dipelajari tanpa terikat waktu dan tempat. Guru akuntansi di SMA Negeri 2 Blitar sangat mendukung penelitian dan pengembangan perangkat pembelajaran ini, karena dengan adanya kurikulum baru 2013, perangkat ini sebagai salah satu referensi sehingga dapat mencapai tujuan yang diharapkan. Siswa yang biasanya kurang memperhatikan, diharapkan dengan adanya modul dari perangkat ini akan tertarik dan dapat mengerti dan memahami materi yang telah disampaikan dengan lebih mudah.

\section{b. Pengembangan Rancangan Perangkat Pembelajaran Akuntansi berbasis Inkuri}

Pada tahap awal dalam mendesain produk perangkat pembelajaran akuntansi berbasis inkuiri yang akan dikembangkan, peneliti mengkaji terhadap silabus yang ditetapkan dalam kurikulum 2013 sehingga pada pengembangan materi yang akan dimuat dalam perangkat pembelajaran akuntansi berbasis inkuri sesuai dengan silabus kurikulum 2013 dan dapat mencapai tujuan yang tercermin pada silabus.

Pada tahap ini peneliti juga mengumpulkan pustaka - pustaka yang mencangkup materi laporan keuangan perusahaan jasa yang sesuai dengan kurikulum dan silabus yang dikembangkan, juga sumber-sumber yang relevan untuk mendukung materi yang akan dikembangkan dalam perangkat pembelajaran akuntansi ini. Sumber - sumber yang dikumpulkan sebagai acuan dan dalam melakukan perencanaan dengan membuat desain produk. Peneliti juga mengumpulkan pustaka lain berupa gambar-gambar dan kasus - kasus pada internet.

\section{c. Membuat Perangkat Pembelajaran Akuntansi berbasis Inkuri}

Hasil dari analisi situasi awal memberikan masukan dalam pengembangan perangkat pembelajaran akuntansi berbasis inkuri. Hasil tersebut digunakan sebagai dasar dalam menentukan komponen yang akan dimuat dalam modul pembelajaran akuntansi berbasis inkuri sehingga dapat menarik dan mudah dalam memahami materi laporan keuangan perusahaan jasa. Modul yang diciptakan mampu memenuhi harapan dan dapat dimanfaatkan dalam pembelajaran.

Isi modul pembelajaran akuntansi berbasis multimedia ini terdiri dari soal - soal dan kasus - kasus sehingga peserta didik mampu berpikir kritis meningkat prestasi belajarnya. Dengan tampilan yang menarik dalam modul tersebut, dapat meningkatkan motivasi dan minat siswa.

\section{d. Penilaian Uji Validitas}

Pengembangan perangkat pembelajaran akuntansi berbasis inkuiri dua orang ahli yang terdiri dari dosen dan guru. Validasi dosen dan guru merupakan salah satu langkah untuk mendapatkan masukan dan tanggapan dalam menyempurnakan produk yang dikembangkan.

\section{Validasi Ahli Materi}

Data validasi ahli materi diperoleh dari ahli materi akuntansi dalam materi laporan keuangan perusahaan jasa untuk menentukan ketepatan materi yang ada dalam perangkat pembelajaran akuntansi berbasis inkuri ini. Disini validator merupakan ahli dalam bidang akuntansi. Validator ahli materi dalam pengembangan ini adalah Ibu Ika Putri Larasati, S.E., M.Com yang merupakan dosen Jurusan Akuntansi Fakultas Ekonomi Universitas Negeri Malang dan mempunya pengalaman bekerja sebagai Akuntan. 


\section{Validasi Ahli Pendidikan}

Data validasi ahli pendidikan diperoleh dari ahli pendidikan akuntansi dalam materi laporan keuangan perusahaan jasa untuk menentukan ketepatan perangkat pembelajaran yang ada dalam pengembangan perangkat pembelajaran akuntansi berbasis inkuri ini. Disini validator merupakan guru akuntansi di SMA Negeri 2 Blitar yang telah mengajar akuntansi di SMA tersebut. Validator disini adalah Dra. Sri Rahayuningtyas yang merupakan guru akuntansi senior di SMA Negeri 2 Blitar.

\section{e. Revisi Produk I}

1. Revisi Ahli Materi

Revisi ahli materi dilakukan untuk memperbaiki modul dari perangkat pembelajaran akuntansi berbasis inkuri ini. Revisi tersebut adalah ralat tentang contoh kasus yang kurang jelas penjabarannya. Dan juga mengenai kasus yang digunakan lebih dikembangkan lagi. Dalam pengembangan ini ahli materi adalah Ibu Ika Putri Larasati, S.E., M.Com yang merupakan dosen Jurusan Akuntansi Fakultas Ekonomi Universitas Negeri Malang dan mempunya pengalaman bekerja sebagai Akuntan.

\section{Revisi Ahli Pendidikan}

Revisi Ahli RPP ilakukan untuk memperbaiki RPP dari perangkat pembelajaran akuntansi berbasis inkuri ini. Revisi tersebut adalah tentang tujuan pembelajaran yang masih kurang sempurna. Langkah - langkah pembelajaran yang ada dalam RPP perlu dikembangkan lebih baik lagi agar jelas step by step. Ahli pendidikan dalam pengembangan RPP ini adalah Dra. Sri Rahayuningyas selaku guru yang mengajar mata pelajaran akuntansi, yang memilik latar belakang S1 Pendidikan Akuntansi, dan menguasai materi dan sudah lama mengajar di SMA Negeri 2 Blitar

\section{f. Uji Coba Lapangan Terbatas}

Uji coba lapangan terbatas dilakukan untuk memperbaiki perangkat pembelajaran akuntansi berbasis inkuiri ditinjau dari pengguna. Uji coba lapangan terbatas dilakukan di SMA Negeri 2 Blitar di kelas XI.IS.5 .

\section{Data Kuantitatif}

Data kuantitatif yang diperoleh merupakan hasil dari angket tertutup dan hasil tes, data kuantitatif ini digunakan sebagai dasar untuk menentukan kevalidan/kelayakan perangkat pembelajaran akuntansi berbasis inkuri ini. Data kuantitatif yang diperoleh dari validasi dan tes yang disajikan sebagai berikut:

Tabel Data Validasi Ahli Materi (Modul Siswa)

\begin{tabular}{|c|c|c|c|c|}
\hline \multirow{2}{*}{ NO } & \multirow{2}{*}{ KETERANGAN } & \multicolumn{2}{|c|}{ Skor } & \multirow{2}{*}{$\frac{\text { Persentase }}{\%}$} \\
\hline & & $\mathbf{X i}$ & $\mathbf{Y i}$ & \\
\hline \multicolumn{5}{|c|}{ Penyajian Materi } \\
\hline 1. & Materi yang disajikan sudah sesuai dengan kurikulum yang berlaku & 3 & 4 & $75 \%$ \\
\hline 2. & Materi yang disajikan sudah sesuai dengan Kompetensi Inti & 4 & 4 & $100 \%$ \\
\hline 3. & Materi yang disajikan sudah sesuai dengan Kompetensi Dasar & 4 & 4 & $100 \%$ \\
\hline 4. & Materi yang disajikan sudah sesuai dengan tujuan pembelajaran. & 4 & 4 & $100 \%$ \\
\hline 5. & Bahasa yang ditangguhkan dalam modul pembelajaran sudah jelas & 3 & 4 & $75 \%$ \\
\hline 6. & $\begin{array}{l}\text { Bahasa yang digunakan dalam modul pembelajaran sederhana dan } \\
\text { mudah dimengerti }\end{array}$ & 3 & 4 & $75 \%$ \\
\hline 7. & Penyajian materi tentang laporan keuangan perusahaan jasa & 2 & 4 & $50 \%$ \\
\hline 8. & $\begin{array}{l}\text { Teks, tabel, dan gambar dalam modul pembelajaran akuntansi berbasis } \\
\text { inkuri memudahkan siswa untuk memahami konsep laporan keuangan } \\
\text { perusahaan jasa }\end{array}$ & 2 & 4 & $50 \%$ \\
\hline 9. & $\begin{array}{l}\text { Kecukupan contoh soal dalam modul pembelajaran akuntansi berbasis } \\
\text { inkuiri sudah cukup }\end{array}$ & 2 & 4 & $50 \%$ \\
\hline \multicolumn{5}{|c|}{ Inkuiri } \\
\hline
\end{tabular}




\begin{tabular}{|c|c|c|c|c|}
\hline 10 & $\begin{array}{l}\text { Modul yang digunakan akan mampu membangkitkan rasa ingin tahu } \\
\text { ketika siswa membacanya dan mendorong siswa untuk berpikir kritis }\end{array}$ & 3 & 4 & $75 \%$ \\
\hline 11. & $\begin{array}{l}\text { Modul yang digunakan akan mampu merangsang siswa untuk } \\
\text { mempertanyakan suatu hal lebih jauh, dan mencari jawaban secara } \\
\text { mandiri. }\end{array}$ & 3 & 4 & $75 \%$ \\
\hline \multicolumn{5}{|c|}{ Soal Latihan (Evaluasi) } \\
\hline 12. & $\begin{array}{l}\text { Soal latihan yang disajikan dalam modul pembelajaran akuntansi } \\
\text { berbasis inkuiri sudah sesuai dalam mencapai tujuan pembelajaran }\end{array}$ & 4 & 4 & $100 \%$ \\
\hline 13. & $\begin{array}{l}\text { Soal latihan yang disajikan dalam program media pembelajaran } \\
\text { akuntansi berbasis multimedia sudah sesuai dengan materi laporan } \\
\text { keuangan perusahaan jasa }\end{array}$ & 4 & 4 & $75 \%$ \\
\hline 14. & $\begin{array}{l}\text { Soal latihan dalam modul pembelajaran akuntansi berbasis inkuri } \\
\text { mempermudah pemahaman materi tentang laporan keuangan } \\
\text { perusahaan jasa }\end{array}$ & 4 & 4 & $100 \%$ \\
\hline \multicolumn{5}{|c|}{ Lain-lain } \\
\hline 15. & $\begin{array}{l}\text { Petunjuk penggunaan program modul pembelajaran akuntansi berbasis } \\
\text { inkuiri mudah dipahami }\end{array}$ & 3 & 4 & $75 \%$ \\
\hline 16. & $\begin{array}{l}\text { Modul pembebelajaran akuntansi berbasis inkuiri ini akan bermanfaat } \\
\text { bagi siswa }\end{array}$ & 3 & 4 & $75 \%$ \\
\hline 17. & $\begin{array}{l}\text { Penggunaan program media pembelajaran akuntansi berbasis inkuiri } \\
\text { memudahkan siswa belajar }\end{array}$ & 4 & 4 & $100 \%$ \\
\hline \multicolumn{2}{|r|}{ Total } & \multicolumn{3}{|c|}{$\begin{array}{l}1375 \% \\
\mathbf{1 3 7 5 / 1 7 0 0 x ~ 1 0 0 \% =} \\
\mathbf{8 0 , 8 8 \%}\end{array}$} \\
\hline
\end{tabular}

Tabel 4.2 Data Validasi Ahli Materi (Modul Panduan Guru)

\begin{tabular}{|c|c|c|c|c|}
\hline \multirow{2}{*}{ NO } & \multirow{2}{*}{ KETERANGAN } & \multicolumn{2}{|c|}{ Skor } & \multirow{2}{*}{$\frac{\text { Persentase }}{\%}$} \\
\hline & & $\mathbf{X i}$ & Yi & \\
\hline \multicolumn{5}{|c|}{ Penyajian Materi } \\
\hline 1. & Materi yang disajikan sudah sesuai dengan kurikulum yang berlaku & 3 & 4 & $75 \%$ \\
\hline 2. & Materi yang disajikan sudah sesuai dengan Kompetensi Inti & 4 & 4 & $100 \%$ \\
\hline 3. & Materi yang disajikan sudah sesuai dengan Kompetensi Dasar & 4 & 4 & $100 \%$ \\
\hline 4. & Materi yang disajikan sudah sesuai dengan tujuan pembelajaran. & 4 & 4 & $100 \%$ \\
\hline 5. & Bahasa yang ditangguhkan dalam modul pembelajaran sudah jelas & 3 & 4 & $75 \%$ \\
\hline 6. & $\begin{array}{l}\text { Bahasa yang digunakan dalam modul pembelajaran sederhana dan } \\
\text { mudah dimengerti }\end{array}$ & 3 & 4 & $75 \%$ \\
\hline 7. & Penyajian materi tentang laporan keuangan perusahaan jasa & 2 & 4 & $50 \%$ \\
\hline 8. & $\begin{array}{l}\text { Teks, tabel, dan gambar dalam modul pembelajaran akuntansi berbasis } \\
\text { inkuri memudahkan siswa untuk memahami konsep laporan keuangan } \\
\text { perusahaan jasa }\end{array}$ & 3 & 4 & $75 \%$ \\
\hline 9. & $\begin{array}{l}\text { Kecukupan contoh soal dalam modul pembelajaran akuntansi berbasis } \\
\text { inkuiri sudah cukup }\end{array}$ & 2 & 4 & $50 \%$ \\
\hline \multicolumn{5}{|c|}{ Inkuiri } \\
\hline 10 & $\begin{array}{l}\text { Modul yang digunakan akan mampu membantu guru untuk } \\
\text { membangkitkan rasa ingin tahu ketika siswa membacanya dan } \\
\text { mendorong siswa untuk berpikir kritis }\end{array}$ & 3 & 4 & $75 \%$ \\
\hline 11. & $\begin{array}{l}\text { Modul yang digunakan akan mampu membantu guru untuk merangsang } \\
\text { siswa mempertanyakan suatu hal lebih jauh, dan mencari jawaban } \\
\text { secara mandiri. }\end{array}$ & 3 & 4 & $75 \%$ \\
\hline \multicolumn{5}{|c|}{$\begin{array}{l}\text { Soal Latihan (Evaluasi) } \\
\end{array}$} \\
\hline 12. & $\begin{array}{l}\text { Soal latihan yang disajikan dalam modul pembelajaran akuntansi } \\
\text { berbasis inkuiri sudah sesuai dalam mencapai tujuan pembelajaran }\end{array}$ & 4 & 4 & $100 \%$ \\
\hline 13. & $\begin{array}{l}\text { Soal latihan yang disajikan dalam program media pembelajaran } \\
\text { akuntansi berbasis multimedia sudah sesuai dengan materi laporan } \\
\text { keuangan perusahaan jasa }\end{array}$ & 4 & 4 & $100 \%$ \\
\hline
\end{tabular}




\begin{tabular}{|c|c|c|c|c|}
\hline 14. & $\begin{array}{l}\text { Soal latihan dalam modul pembelajaran akuntansi berbasis inkuri } \\
\text { mempermudah pemahaman materi tentang laporan keuangan } \\
\text { perusahaan jasa }\end{array}$ & 4 & 4 & $100 \%$ \\
\hline \multicolumn{5}{|c|}{ Lain-lain } \\
\hline 15. & $\begin{array}{l}\text { Petunjuk penggunaan program modul pembelajaran akuntansi berbasis } \\
\text { inkuiri mudah dipahami }\end{array}$ & 3 & 4 & $75 \%$ \\
\hline 16. & Kunci jawaban dalam modul sudah tepatt dan sesuai & 3 & 4 & $75 \%$ \\
\hline 17 & $\begin{array}{l}\text { Modul pembebelajaran akuntansi berbasis inkuiri ini akan bermanfaat } \\
\text { bagi siswa }\end{array}$ & 4 & 4 & $100 \%$ \\
\hline 18. & $\begin{array}{l}\text { Penggunaan program modul pembelajaran akuntansi berbasis inkuiri } \\
\text { memudahkan siswa belajar }\end{array}$ & 4 & 4 & $100 \%$ \\
\hline \multirow{2}{*}{\multicolumn{2}{|c|}{$\begin{array}{ll} & \text { Total } \\
\end{array}$}} & & & $1500 \%$ \\
\hline & & \multicolumn{3}{|c|}{$\begin{array}{l}\text { 1500/1800x100\% }= \\
83,33 \%\end{array}$} \\
\hline
\end{tabular}

\section{Data Validasi Ahli Pendidikan}

\begin{tabular}{|c|c|c|c|c|}
\hline \multirow{2}{*}{ NO } & \multirow{2}{*}{ KETERANGAN } & \multicolumn{2}{|c|}{ Skor } & \multirow{2}{*}{$\frac{\text { Persentase }}{\%}$} \\
\hline & & $\mathbf{X i}$ & $\mathbf{Y i}$ & \\
\hline \multicolumn{5}{|c|}{ Format } \\
\hline 1. & Pembagian materi dalam RPP ini sudah jelas & 4 & 4 & $100 \%$ \\
\hline 2. & Pengaturan ruang/tata letak dalam RPP ini sudah sesuai & 4 & 4 & $100 \%$ \\
\hline 3. & Jenis dan ukuran huruf yang digunakan dalam RPP ini sudah sesuai & 4 & 4 & $100 \%$ \\
\hline \multicolumn{5}{|c|}{ Komponen RPP } \\
\hline 4. & Identitas mata pelajaran dalam RPP sudah lengkap & 4 & 4 & $100 \%$ \\
\hline 5. & Kompetensi inti yang disajikan sudah lengkap & 4 & 4 & $75 \%$ \\
\hline 6. & $\begin{array}{l}\text { Kompetensi dasar yang disajikan sudah lengkap dan sesuai dengan } \\
\text { kompetensi inti }\end{array}$ & 4 & 4 & $100 \%$ \\
\hline 7. & Tujuan pembelajaran disusun secara lengkap & 4 & 4 & $100 \%$ \\
\hline 8. & Materi pembelajaran dijabarkan & 3 & 4 & $75 \%$ \\
\hline 9. & Alokasi waktu cukup & 4 & 4 & $100 \%$ \\
\hline 10. & Metode pembelajaran disajikan secara jelas & 3 & 4 & $75 \%$ \\
\hline 11. & Langkah - langkah kegiatan disajikan secara jelas & 4 & 4 & $100 \%$ \\
\hline 12. & Sumber belajar disajikan jelas & 4 & 4 & $100 \%$ \\
\hline \multicolumn{5}{|c|}{ Bahasa } \\
\hline 13. & Tata bahasa yang digunakan dalam RPP ini sudah baik & 4 & 4 & $100 \%$ \\
\hline 14. & $\begin{array}{l}\text { Kesederhanaan struktur kalimat yang digunakan dalam RPP ini sudah } \\
\text { baik }\end{array}$ & 4 & 4 & $100 \%$ \\
\hline 15. & Petunjuk atau arahan yang digunakan dalam RPP ini sudah jelas & 4 & 4 & $100 \%$ \\
\hline 16. & Bahasa yang digunakan dalam RPP ini komunikatif & 4 & 4 & $100 \%$ \\
\hline \multicolumn{5}{|c|}{ Lain-lain } \\
\hline 17. & $\begin{array}{l}\text { Rencana Pelaksanaan Pembelajarn ini sudah sesuai dengan silabus yang } \\
\text { digunakan }\end{array}$ & 3 & 4 & $75 \%$ \\
\hline 18. & $\begin{array}{l}\text { Rencana Pelaksanaan Pembelajaran akuntansi berbasis inkuiri } \\
\text { bermanfaat bagi proses pembelajaran }\end{array}$ & 4 & 4 & $100 \%$ \\
\hline 19. & $\begin{array}{l}\text { Rencana Pelaksanaan Pembelajaran akuntansi berbasis inkuri } \\
\text { memudahkan guru dalam pelaksanaan inkuri di kelas }\end{array}$ & 4 & 4 & $100 \%$ \\
\hline 20. & $\begin{array}{l}\text { Rencana Pelaksanaan Pembelajaran akuntansi berbasis inkuri } \\
\text { memudahkan guru dalam pelaksanaan proses pembelajaran }\end{array}$ & 4 & 4 & $100 \%$ \\
\hline & Total & & & $1900 \%$ \\
\hline & & \multicolumn{3}{|c|}{$\begin{array}{l}\text { 1900/2000x } 100 \%= \\
95 \%\end{array}$} \\
\hline
\end{tabular}

Dari tabel data hasil validasi ahli pendidikan, dapat disimpulkan bahwa perangkat pembelajaran akuntansi berbasis inkuri yang dikembangkan yang telah dikembangkan tidak 
Dari tabel 4.4 Data hasil validasi uji coba lapangan terbatas yang menunjukkan persentase $85,93 \%$, dapat disimpulkan bahwa modul pembelajaran akuntansi yang telah dikembangkan tidak memerlukan revisi karena memiliki nilai yang memiliki kriteria valid dan layak digunakan.

\section{a. Data Kualitatif}

Instrument angket tertutup selain menghasilkan data kuantitatif juga menghasilkan data kualitatif yang diperoleh dari saran, kritik dan pendapat secara umum tentang perangkat pembelajaran akuntansi berbasis inkuiri yang dikembangkan. Saran, kritik dan pendapat secara umum yang diberikan oleh ahli materi dan uji lapangan terbatas (siswa) dari hasil pengamatan perangkat pembelajaran akuntansi berbasis inkuri digunakan oleh peneliti sebagai bahan pertimbangan untuk memperbaiki perangkat pembelajaran akuntansi berbasis inkuri yang dikembangkan.

\section{A. Analisis Data}

\section{Analisis Data Validasi}

Data - data yang dihasilkan pada tahap validasi dianalisis dengan menggunakan teknik analisis deskriptif persentase yaitu teknik atau cara yang digunakan untuk mengubah data kuantitatif menjadi bentuk persentase kemudian diinterpretasikan dengan kalimat yang bersifat kualitatif yang terdiri dari analisis data ahli materi dan data uji coba lapangan terbatas (siswa). Analisis data dilakukan pada setiap item pertanyaan dan total keseluruhan dengan item pertanyaan. Analisis data tersebut diuraikan sebagai berikut: Tabel Analisis Validasi Ahli Materi (Modul Siswa)

\begin{tabular}{clcc}
\hline No. & Komponen yang dinilai & Persentase $\%$ & Kriteria Kevalidan \\
\hline 1 & Penyajian materi & $75,00 \%$ & Valid / layak digunakan \\
\hline 2 & Inkuiri & $75,00 \%$ & Valid / layak digunakan \\
\hline 3 & Soal Latihan (evaluasi) & $91,67 \%$ & Valid / layak digunakan \\
\hline 4 & Lain-lain & $83,33 \%$ & Valid / layak digunakan \\
\hline \multicolumn{2}{c}{ Rata-rata } & $80,88 \%$ & Valid / layak digunakan \\
\hline
\end{tabular}

Sumber: Angket Validasi Ahli Materi

Tabel Analisis Validasi Ahli Materi (Modul Panduan Guru)

\begin{tabular}{clcc}
\hline No. & Komponen yang dinilai & Persentase \% & Kriteria Kevalidan \\
\hline 1 & Penyajian materi & $77,78 \%$ & Valid / layak digunakan \\
\hline 2 & Inkuiri & $75,00 \%$ & Valid / layak digunakan \\
\hline 3 & Soal Latihan (evaluasi) & $100 \%$ & Valid / layak digunakan \\
\hline 4 & Lain-lain & $87,5 \%$ & Valid / layak digunakan \\
\hline & Rata-rata & $87,5 \%$ & Valid / layak digunakan \\
\hline
\end{tabular}

Sumber: Angket Validasi Ahli Materi

Berdasarkan Tabel Analisis Validasi Ahli Materi dalam modul siswa dapat dilihat dari hasil analis terhadap angket validasi oleh ahli materi dari aspek penyajian materi diperoleh kriteria valid dan layak digunakan dengan persentanse $75 \%$ pada aspek penyajian materi, aspek inkuiri memperoleh kriteria valid dan dapat digunakan dengan persentase sebesar 75,00 $\%$, dalam aspek soal latihan juga memenuhi kriteria valid dan dapat digunakan dengan eprsentase 91,67\%, dan aspek lain - lain dengan kriteria valid dan dapat digunakan dengan persentase 83,33\%. Berdasarkan Tabel 4.10 Analisis Validasi Ahli Materi dalam modul guru dapat dilihat dari hasil analis terhadap angket validasi oleh ahli materi dari aspek penyajian materi diperoleh kriteria valid dan layak digunakan dengan persentanse $77,78 \%$ pada aspek penyajian materi, aspek inkuiri memperoleh kriteria valid dan dapat digunakan dengan persentase sebesar 75,00 \%, dalam aspek soal latihan juga memenuhi kriteria valid dan dapat digunakan dengan persentase $100 \%$, dan aspek lain - lain dengan kriteria valid dan dapat digunakan dengan persentase $87,5 \%$. Hasil validasi perangkat pembelajaran akuntansi 
berbasis inkuri dari ahli materi diperoleh rata - rata persentase sebesar 80,88 \% dan 83,33\% maka pengembangan pperangkat pembelajaran akuntansi berbasis inkuri dinyaatkan valid dan layak digunakan di SMA Negeri 2 Blitar.

Tabel Analisis Validasi Ahli Pendidikan

\begin{tabular}{clcc}
\hline No & Komponen yang dinilai & Persentase \% & Kriteria Kevalidan \\
\hline 1 & Format & $100,00 \%$ & Valid / layak digunakan \\
\hline 2 & Komponen & $91,67 \%$ & Valid / layak digunakan \\
\hline 3 & Bahasa & $100,00 \%$ & Valid / layak digunakan \\
\hline 4 & Lain - lain & $93,75 \%$ & Valid / layak digunakan \\
\hline \multicolumn{2}{c}{ Rata-rata } & $95,00 \%$ & Valid / layak digunakan \\
\hline
\end{tabular}

Sumber: Angket Validasi Ahli Pendidikan

Berdasarkan Tabel Analisis Validasi Ahli Pendidikan dapat dilihat hasil analisis terhadap angket validasi oleh ahli pendidikan dari format RPP dapat diperoleh kriteria valid dan dapat digunakan dengan persentase sebesar 100,00 \%, aspek komponen RPP diperoleh kriteria valid dan layak digunakan dengan persentase sebesar $100 \%$, aspek keinteraktifan diperoleh kriteria valid dan dapat digunakan dengan persentase 95,5\%, sedangkan aspek bahasa memperoleh kriteria valid dan dapat digunakan dengan persentase sebesar $100,00 \%$, dan aspek lain-lain memperoleh kriteria valid dan dapat digunakan dengan persentase 93,75\%. Hasil validasi perangkat pembelajaran akuntansi berbasis inkuiri dari ahli pendidikan memperoleh rata - rata persentase sebesar 95,0 \% dan dapat disimpulkan bahwa perangkat pembelajaran akuntansi berbasis inkuiri yang telah dikembangkan oleh peneliti valid dan layak digunakan dalam proses pembelajaran akuntansi di SMA Negeri 2 Blitar.

Tabel 4.11 Analisis Uji Coba Lapangan Terbatas (pengguna)

\begin{tabular}{clrc}
\hline No. & Komponen yang dinilai & Persentase \% & Kriteria Kevalidan \\
\hline 1 & Bahan penarik perhatian & $86,74 \%$ & Valid/ dapat digunakan \\
\hline 2 & Penyajian materi & $86,61 \%$ & Valid / dapat digunakan \\
\hline 3 & Inkuiri & $79,56 \%$ & Cukup Valid / dapat digunakan \\
\hline 4 & Soal latihan & $86,93 \%$ & Valid / dapat digunakan \\
\hline 5 & Keinteraktifan & $85,23 \%$ & Valid / dapat digunakan \\
\hline 6 & Lain-lain & $87,63 \%$ & Valid / dapat digunakan \\
\hline & Rata-rata & $84,87 \%$ & Valid / dapat digunakan \\
\hline
\end{tabular}

Sumber: Angket Validasi Lapangan Terbatas

Berdasarkan Tabel Analisis Uji Coba Lapangan Terbatas (siswa) dapat dilihat hasil analisis terhadap angket validasi oleh uji coba lapangan terbatas (siswa) dari aspek bahan penarik perhatian diperoleh kriteria valid dan dapat digunakan dengan persentase sebesar $86,74 \%$, aspek penyajian materi diperoleh kriteria valid dan dapat digunakan dengan persentase $86,61 \%$, aspek inkuiri memperoleh kriteria valid dan dapat digunakan dengan persentase sebesar 79,55\%, aspek keinteraktifan juga memperoleh kriteria valid dan dapat digunakan dengan persentase sebesar 85,23 \%, dan aspek lain-lain memperoleh kriteria valid dan dapat digunakan dengan persentase sebesar 87,63 \%. Hasil dari uji coba lapangan terbatas (siswa) diperoleh rata - rata persentase sebesar 84,87 \% dan dapat disimpulkan bahwa perangkat pembelajaran akuntansi berbasis inkuri yang telah dikembangkan oleh peneliti valid dan layak untuk digunakan dalam proses pembelajaran akuntansi di SMA Negeri 2 Blitar.

Tabel Analisis Keseluruhan Validasi

\begin{tabular}{clcc}
\hline No & \multicolumn{1}{c}{ Komponen yang dinilai } & Persentase \% & Kriteria kevalidan \\
\hline 1 & $\begin{array}{l}\text { Rata - rata validasi ahli materi } \\
\text { (modul siswa) }\end{array}$ & $80,88 \%$ & Valid / layak digunakan \\
\hline 2 & $\begin{array}{l}\text { Rata - rata validasi ahli materi } \\
\text { (modul panduan guru) }\end{array}$ & $83,33 \%$ & Valid / layak digunakan \\
\hline 3 & Rata - rata validasi ahli pendidikan & $95,5 \%$ & Valid / layak digunakan \\
\hline 4 & $\begin{array}{l}\text { Rata - rata validasi uji coba lapangan } \\
\text { terbatas (pengguna) }\end{array}$ & $84,87 \%$ & Valid / layak digunakan \\
\hline
\end{tabular}




\begin{abstract}
Rata - rata keseluruhan validasi $86,15 \%$ Valid / layak digunakan

Sumber: Angket Validasi Ahli Materi, Ahli Media, dan Lapangan Terbatas

Berdasarkan Tabel Analisis Keseluruhan Validasi diperoleh dari ahli materi dengan nilai rata - rata persentase $80,88 \%$ dan $83,33 \%$. Ahli pendidikan diperoleh nilai rata - rata persentase sebesar 95,5\% dan uji coba lapangan terbatas diperoleh nilai rata- rata sebesar $84,87 \%$. Sehingga rata- rata persentase keseluruhan sebesar $86,15 \%$ dan dapat disimpulkan bahwa perangkat pembelajaran akuntansi berbasis inkuiri yang telah dikembangkan valid dan layak digunakan dalam proses pembelajaran akuntansi di SMA Negeri 2 Blitar.
\end{abstract}

\title{
2. Analisis Data Hasil Pretest dan Posttest
}

Hasil validasi yang telah dilakukan dan memperoleh hasil bahwa perangkat pembelajaran akuntansi berbasis inkuri yang telah dikembangkan layak digunakan sebagai media pendukung dalam proses pembelajaran di dalam kelas, sehingga untuk menguji hal tersebut digunakan one group pretest-postest design untuk memperkuat apakah perangkat dapat digunakan sebagai perangkat pembelajaran yang layak digunakan di dalam kelas dengan dibuktikan dengan hasil belajar siswa

Berikut ini adalah hasil nilai pretest dan posttest pada saat uji coba lapangan terbatas (siswa):

Tabel Nilai Pretest dan Posttest

\begin{tabular}{|c|c|c|c|c|}
\hline NO & NAMA SISWA & PRE TEST & POST TEST & GS \\
\hline 1 & AHMAD KHOIRUL MISPAN & 60 & 100 & 40 \\
\hline 2 & ARDILAH DWI ANGGRAENI & 60 & 80 & 20 \\
\hline 3 & CATUR BUDI PRASETYO & 70 & 80 & 10 \\
\hline 4 & DESTY EKA SETYOWATI & 80 & 100 & 20 \\
\hline 5 & DHARMASTUTI AYU MULYATI & 100 & 100 & 0 \\
\hline 6 & DIMAS YUDHISTIRA WIRATAMA & 80 & 100 & 20 \\
\hline 7 & DWI RETNO APRILIA & 80 & 100 & 20 \\
\hline 8 & ELYSABETH FEBRI CRISTIANIK & 90 & 90 & 0 \\
\hline 9 & ERIAN SAGA ANGGRAENI & 70 & 80 & 10 \\
\hline 10 & FINNA ALIMIA & 60 & 80 & 20 \\
\hline 11 & GILDA SACHI & 60 & 100 & 40 \\
\hline 12 & GLADYS PRAMESTY & 60 & 100 & 40 \\
\hline 13 & HEA IGAP SETIYOWATI PUTRI & 70 & 90 & 20 \\
\hline 14 & KHALEDA YEA & 80 & 100 & 20 \\
\hline 15 & LUAYUL CHOIRIYAH & 80 & 100 & 20 \\
\hline 16 & MAULANA YUSUF & 50 & 100 & 50 \\
\hline 17 & NURUL HDAYAH & 60 & 100 & 40 \\
\hline 18 & OKKY ALIVIANA PUTRI & 60 & 90 & 30 \\
\hline 19 & OVAN GALIH WILLYANDI & 50 & 100 & 50 \\
\hline 20 & PAULINA AYU DESITA WATI & 50 & 90 & 40 \\
\hline 21 & PRETTY NOVITASARI & 70 & 80 & 10 \\
\hline 22 & REKA EVRIANA & 50 & 80 & 30 \\
\hline 23 & RIDHO FAJAR FENDI INDRATAMA & 50 & 80 & 30 \\
\hline 24 & RISKI AYU DIANA & 60 & 80 & 20 \\
\hline 25 & RISQA RIFATUL UMAMI & 70 & 90 & 20 \\
\hline 26 & RITA RATNA DILA & 80 & 80 & 0 \\
\hline
\end{tabular}




\begin{tabular}{|c|l|c|c|c|}
27 & RIZKY MEI RAHAYU & 70 & 100 & 30 \\
\hline 28 & SAFIRA ELFANY & 70 & 100 & 30 \\
\hline 29 & SELA RATNASARI & 60 & 100 & 40 \\
\hline 30 & SESILIA OCTA DEWI & 60 & 90 & 30 \\
\hline 31 & SHELLA AGDITIANINGRUM & 60 & 90 & 30 \\
\hline 32 & SULFI NUR CAHYANTI & 70 & 100 & 30 \\
\hline 33 & TRI ISTA AYOMI & 80 & 100 & 20 \\
\hline
\end{tabular}

Dari tabel di atas dapat dilihat bahwa nilai siswa sebelum menggunakan perangkat pembelajaran akuntansi berbasis inkuiri dan sesudah menggunakan perangkat pembelajaran akuntansi berbasis inkuri mengalami perbedaan. Dimana saat mereka hanya menggunakan pembelajaran konvensional hanya mendapat nilai kecil dibanding saat mereka melakukan proses pembelajaran dengan menggunakan perangkat pembelajaran akuntansi berbasis inkuri.

\section{B. Revisi dan Produk Akhir Pengembangan}

\section{Revisi Produk II}

Revisi produk kedua ini didapat dari uji coba lapangan terbatas dan dari kesimpulan hasil analisis yang ada, terdapat berberapa revisi dari uji coba lapangan terbatas, yaitu cover kurang menarik. Beberapa contoh soal dalam modul ini juga diperbaiki karena ada beberapa kesalahan penulisan.

\section{Produk Akhir}

Berdasarkan analisis data hasil validasi ahli materi, ahli pendidikan dan uji coba lapangan terbatas, dapat disimpulkan bahwa media pembelajaran akuntansi berbasis multimedia dalam materi laporan keuangan perusahaan jasa telah dinyatakan valid dan layak digunakan sebagai perangkat pembelajaran yang mandiri. Namun demikian kritik dan saran tentang perangkat pembelajaran akuntansi berbasis inkuri menjadi bahan pertimbangan pada tahap revisi produk, hal ini dilakukan dengan tujuan untuk lebih mengoptimalkan manfaat perangkat pembelajaran akuntansi berbasis inkuri sebagai perangkat pembelajaran yang mandiri. Produk akhir pengembangan ini berupa perangkat pembelajaran akuntansi berbasis inkuri yang dapat digunakan dalam proses pembelajaran akuntansi di SMA Negeri 2 Blitar.

\section{KAJIAN DAN SARAN}

Kajian produk yang telah direvisi berupa perangkat pembelajaran akuntansi berbasis inkuri di SMA Negeri 2 Blitar. Produk yang diuraikan adalah produk jadi berupa Rencana Pelaksanaan Pembelajaran dan Modul yang telah melalui proses revisi berdasarkan uji dari validator dan uji coba lapangan terbatas (siswa).

Perangkat pembelajaran merupakan segala sesuatu yang dapat digunakan untuk bahan pembelajaran, sehingga dapat merangsang perhatian, minat, pikrian, dan perasaan siswa dalam kegiatan belajar untuk mencapai tujuan pembelajaran. Perangkat pembelajaran akuntansi berbasis inkuiri merupakan salah satu penunjang dalam pembelajaran akuntansi di SMA Negeri 2 Blitar.

Komponen inti dari perangkat pembelajaran akuntansi berbasis inkuiri yang telah dikembangkan adalah materi pembelajaran yang ditujukan untuk mencapai tujuan pembelajaran sesuai dengan standart kompetensi dan kompetensi dasar pada kurikulum di SMA Negeri 2 Blitar yang tercermin dalam silabus. Pada perangkat pembelajaran akuntansi berbasis inkuiri dalam materi laporan keuangan perusahaan jasa dimulai dengan kasus yang terjadi di dunia internasional. Hal tersebut diangkat karena dengan memahami kasus, maka siswa akan lebih kritis memahami materi laporan keuangan, karena siswa tidak hanya membutuhkan teori saja. Dengan begitu, penyampaian tentang materi laporan keuangan perusahaan jasa akan lebih mudah. 


\section{Saran Pemanfaatan}

Peneliti menyarankan agar pemanfaatan perangkat pembelajaran akuntansi berbasis inkuri di SMA Negeri 2 Blitar ini dapat dipergunakan secara maksimal. Penggunaannya modul pembelajaran akuntansi berbasis inkuri dalam pembelajaran hendaknya tidak lepas dari pantauan dan bimbingan guru. Agar proses pembelajaran berjalan lancar dan sebaiknya guru sudah mempelajari materi pembelajaran.

\section{Saran Diseminasi}

Penggunaan produk pada skala yang lebih luas perlu mempertimbangkan beberapa hal, antara lain:

a. Penggunaan perangkat pembelajaran akuntansi berbasis inkuiri pada skala yang lebih luas dapat diterapkan secara bertahap. Tahap pertama, guru memberi penjelasan secara garis besar materi laporan keuangan jasa. Tahap kedua, siswa belajar mandiri melalui modul siswa, namun jika masih ada siswa yang belum jelas akan materi yang dijelaskan, maka guru dapat menjelaskan dengan lebih detail .

b. Pengembangan perangkat pembelajaran akuntansi berbasis inkuri digunakan sebagai alternatif dalam mengatasi masalah dalam pembelajaran akuntansi, tetapi untuk penerapan disekolah perlu memperhatikan karakteristik siswa dan sekolah yang bersangkutan.

\section{Saran Pengembangan Lebih Lanjut}

berikut:

Beberapa saran pengembangan produk lebih lanjut dapat dikemukakan sebagai

a. Produk ini dibuat hanya khusus untuk materi laporan keuangan perusahaan jasa. Oleh karena itu, disarankan kepada pengembang produk yang akan datang dapat membuat produk dengan materi yang lain.

b. Keinteraktifan modul dapat ditambahkan dalam modul pembelajaran akuntansi berbasis inkuri yang dikembangkan selanjuntnya.

c. Produk perangkat pembelajaran akuntansi berbasis inkuri ini untuk selanjutnya dapat disempurnakan dengan memperbaiki kualitas tampilan dan kandungan materi yang ada di dalamnya.

d. Peneliti selanjutnya dapat merancang perangkat pembelajaran akuntansi berbasis inkuri dengan konsep lain sehingga modul pembelajaran yang dihasilkan akan lebih baik dari segi konsep maupun materinya.

\section{DAFTAR RUJUKAN}

Arianti, B Fitri. 2012. Meningkatkan Kemampuan Berpikir Kritis Dan Sikap Positif Mahasiswa Akuntansi Melalui Pembelajaran Berbasis Masalah. Program Pascasarjana Universitas Negeri Malang. Tesis tidak diterbitkan.

Arikunto, S. 2009. Dasar - Dasar Evaluasi Pendidikan (Edisi Revisi). Yogyakarta: Bumi Aksara.

Budianingsih, Asri, C. 2005. Belajar dan Pembelajaran Cetakan I. Jakarta: Rineka Cipta

Borg, W.R., \& Gall, M. D. 1983. Education Research an Introduction (4). New york: Logman Inc. 
Degeng, I N.S. 2001. Pengembangan Paket Pembelajaran. Malang LP3 Universitas Negeri Malang.

Daryanto, Drs. 2013. Menyusun Modul (Bahan Ajar untuk Persiapan Guru dalam Mengajar). Yogyakarta: Gava Media

Depdiknas. 2006. Model Silabus dan Rencana Pelaksanaan Pembelajaran Mata Pelajaran Ilmu Pengetahuan Sosial. Jakarta: Departemen Pendidikan Nasional

Depdiknas. 2003. Pedoman Khusus Pembelajaran Tuntas (Mastery Learning). Jakarta: Depdiknas

Gandhi, T.W. 2001. Filsafat Pendidikan. Jogjakarta: A-Ruz Media.

Hamalik, Oemar. 2003. Proses Belajar Mengajar. Jakarta: PT. Bumi Akasara

Hidayat, H Kasan. 2009. Panduan Pelatihan Optimalisasi PQ Anak. Makalah disajikan untuk orang tua siswa TK/SD Kosayu Malang (tanggal 16 juli 2009)

Johnson, E. B. 2007. Contextual Taching And Learning: Menjadikan Kegaiatan BelajarMengajar Mengasyikkan Dan Bermakna. Bandung: Mizan Learning Center (MLC)

Kusuma, Febrian Widya. 2012. Implementasi Model Pembelajaran Kooperatif Tipe Think Pair Share untuk Meningkatkan Aktivitas Belajar Akuntansi Siswa Kelas XI IPS 1 SMA Negeri 2 Wonosari Tahun Ajaran 2011/2012. Jurnal Pendidikan Akuntansi Indonesia, Vol X, No.2, Tahun 2012. Halaman 43-63

Mardianita, Wahyunur. 2012. Penerapan Inkuiri untuk Meningkatkan Kreatifvitas Siswa Kelas X Ma Al Maarif pMateri Geometri. Program Pascasarjana Universitas Negeri Malang. Tesis tidak diterbitkan

Mulyasa, E. 2006. Kurikulum Berbasis Kompetensi. Bandung: PT Remaja Rosdakarya. Ngalimun. 2013. Strategi dan Model Pembelajaran. Yogyakarta:Aswaja Pressindo.

Nugraha, Aziz. 2010. Pengembangan Perangkat Pembelajaran Matematika dengan Pendekatan Metakognitif Berbasis Humanistik untuk Menumbuhkan Berpikir Kritis Siswa pada Materi Himpunan Kelas VII. Jurnal Pendidikan Matematika. ISSN 2089-3639

Sagala, Syaiful. 2006. Konsep dan Makna Pembelajaran. Bandung: Alfabeta

Sa'dijah, Cholis. 2002. Upaya Mengembangkan Bersikap Kritis Melalui Pemecahan Masalah. Jurnal MIPA dan Pembelajaran. Tahun 29 Nomor 1 Januari 2002. Hal 6068

Sanjaya, Wina. 2012. Perencanaan dan Desain Sistem Pembelajaran. Jakarta: Prenada Media Group. 
Slameto, Drs. 2010. Belajar \& Faktor - Faktor yang Mempengaruhinya. Jakarta: Rineka Cipta.

Slavin, RE. 2005. Cooperative learning. Bandung: Pustaka pelajar

Sudaryanto. 2007. Kemampuan Berpikir Kritis (online) (diakses tanggal 12 November 2013)

Sugiyono. 2009. Statistik untuk Penelitian. Bandung: Alfabeta

Sugiyono. 2009. Metode Penelitian Kuantitatif, Kualitatif dan R\&D. Bandung: Alfabeta.

Sudjana, Nana. 2009. Dasar - Dasar Proses Belajar Mengajar. Bandung: Sinar Baru Algensindo.

Sukmadinata, N.S. 2012. Metode Penelitian Pendidikan. Bandung: PT Remaja Rosdakarya.

Ramdani, Agus. 2012. Pengembangan Perangkat Pembelajaran Inkuiri Melalui Kegiatan Lesson Study dan Pengaruh Implementasinya Terhadap Hasil Belajar IPA Biologi dan Ketrampilan Berpikir Kritis Siswa Berkemampuan Akademik Berbeda di SMP Negeri Kota Mataram. Program Pascasarjana Universitas Negeri Malang. Tesis tidak diterbitkan.

Yuliati, Lia. 2008. Model - model Pembelajaran Fisikan/ Teori dan Praktek. Malang: Lembaga Pengembangan Pendidikan dan Pembelajaran (LP3) Universitas Negeri Malang. 